\title{
The Incorporation of International Accounting Concepts in the Curriculum at Private Universities in the State of Pennsylvania
}

\author{
Michael J. Gallagher ${ }^{1}$ \\ ${ }^{1}$ Department of Accounting, DeSales University, PA, USA \\ Correspondence: Michael J. Gallagher, PhD, Department of Accounting, DeSales University, 2755 Station Avenue, \\ Center Valley, PA 18034, USA. Tel: 610-282-1100 ext. 1838. E-mail: michael.gallagher@desales.edu \\ Received: May 17, 2013 \\ Accepted: June 12, 2013 \\ Online Published: July 2, 2013 \\ doi:10.5430/ijba.v4n4p9 \\ URL: http://dx.doi.org/10.5430/ijba.v4n4p9
}

\begin{abstract}
The purpose of this paper is to report the coverage of various topics specific to the coverage of the International Financial Reporting Standards (IFRS). This paper used as a base a survey sent to approximately 50 private colleges and universities in Pennsylvania. The questions ranged from the differences in accounting concepts between the IFRS standards and the United States Generally Accepted Accounting Principles (GAAP) and the cultural influences of financial reporting in today's global economy. A small percentage of the universities have a stand-alone course in international accounting and the coverage of the various differences is not consistent from college to college. This paper will also describe key differences that exist with IFRS and US GAAP.
\end{abstract}

Keywords: international accounting, accounting curriculum, international financial reporting standards

\section{Introduction}

International Financial Reporting Standards (IFRS) is a method of presenting the financial position and results of operations for corporations that has been adopted by "120 nations and reporting jurisdictions" (Benjamin, M. 2/29/2012). The United States is one of the countries that has not adopted IFRS but still uses Generally Accepted Accounting Principles (GAAP) maintained by the Financial Accounting Standards Board (FASB). The Securities and Exchange Commission (SEC) has set and extended deadlines on the incorporation of international standards and is currently working on a convergence project (Deloitte, 2009).

Accounting educators are struggling with the incorporation of international standards in the accounting curriculum. Many private colleges and universities have limited number of courses available to cover a range of accounting topics to prepare students for careers in accounting and the Uniform Certified Public Accounting examination. "The American Accounting Association, whose members are accounting professors, created a task force in 2007 to develop IFRS curricula that could be rolled out to colleges" (Leone, M., 10/8/2009). Accounting professors at private colleges and universities in Pennsylvania were surveyed to determine the progress of incorporating international standards in the curriculum. The results of the survey are listed in Tables one to four and the survey questions are listed in Appendix one.

\section{Methodology}

This study sent a survey to private Pennsylvania Colleges and Universities with undergraduate accounting programs (Pennsylvania Colleges Offering a Major in Accounting - College Toolkit, 12/5/2012). The accounting professors were asked to rate on a scale of $1-5$ the incorporating of international accounting concepts into the undergraduate accounting curriculum. The concepts could be covered in existing courses or by designing a stand-alone course in international accounting. A copy of the survey is in Appendix 1. The survey also asked the professor "Does your university have an elective or required course on International Accounting"? We received 32 surveys that answered the 20 questions concerning incorporating international accounting concepts in the curriculum. Seven of the colleges reported having a stand-alone course in the undergraduate curriculum.

\section{Discussion of Results}

The concepts surveyed were arranged into four groups for analysis. Table one discusses the fundamental differences 
between the IASB standards and the FASB standards. The results demonstrate that professors discussed the concept of IFRS along with the fundamental differences between a principle based set of standards and a rule based set of standards. The results of 3.1 on a scale of 5.0 for both of these concepts illustrates that on the average the general discussion of international versus US GAAP is being addressed in the classroom.

The presentation of IFRS based financial statements scored 2.6 out of 5.0 on the Likert scale. This score is lower than the general discussion of IFRS and the idea of principle based versus rule based guidelines. The two lowest scores in this group include the first time IFRS implementation procedures (1.8) and International Financial Reporting Standards for Small and Medium Size Entities (IFRS for SME's) scored a 1.4.

IFRS allows for a uniform financial reporting standard. As we continue to evolve into a global economy it will be important for international business to have comparable financial statements. For international companies this will allow one standard of financial statements to be used by all subsidiaries regardless of the country they operate in (Saint Joseph's University website, 12/5/2012). The professors at Saint Joseph's and other private universities understand the usefulness of describing the international financial reporting standards to students because it provides a method of understanding the global financial markets.

The use of international standards will allow for comparisons of results of operations and financial position for companies operating in various countries. This is an advantage of global standards recognized by the Securities Exchange Committee (SEC). The area of contention is stated in the July 13, 2012 report "Work Plan for the Consideration of Incorporating International Financial Reporting Standards into the Financial Reporting System for U.S. Issuers Final Staff Report" (Securities Exchange Commission, 7/13/2012). The final staff report concludes "while we applaud principles-based standards, principle-based standards are problematic whenever practice interprets the standards differently, and resulting reporting is excessively diverse" (Securities Exchange Commission, p. 35). The accounting professors discuss this difference in setting and applying standards providing a discussion on the advantages and disadvantages of principle-based (IFRS) versus rule based (US GAAP).

The presentation of IFRS financial statements scored lower than the individual topics (see Tables 1 and 2) with a score of 2.6 and topics including last in first out (LIFO) inventory coverage rate as high as 3.1. The one exception was lease accounting. One of the methods of illustrating financial statement differences in U.S. GAAP and IFRS is to examine 20-F reconciliations. This methodology was presented in a case study in the November, 2007 Issues in Accounting (Henry, E., Lin, S., and Yang, 11/2007). Case studies are a potential pedagogy allowing for the coverage of IFRS statements while providing an opportunity to critically analyze the various components of financial statements along with the differences between U.S. GAAP and IFRS prepared financial statements.

The teaching of the rules for first time implementation of International Financial Reporting Standards (IFRS) scored a 1.8. One of the potential projects that could be used would be to download a financial statement of a company that has implemented IFRS from their local standards and then analyze the first time implementation translation along with the 20-F. This project was accomplished at DeSales University in conjunction with a trip to Peru. The students downloaded the 20-F from Beunaventura Mining 20-F financial statements for 2011 (Beunavenura Mining 20-F, 12/20110. The project resulted in the students comparing both first time implementations of IFRS, IFRS based statements, and U.S. GAAP.

The presentation of IFRS for Small and Medium Size Entities scored the lowest at a 1.4. This method of preparing financial statements may be an alternative for small and medium size entities. IFRS for SME's is a 230 page document ( $85 \%$ decrease from full IFRS) designed to focus on "short term cash flows, liquidity, and solvency" (AICPA, 12/10/2012). The Financial Accounting Standards Board (FASB) is also designing a set of standards for small and medium size entities (AICPA, 12/10/2012). These two methodologies will be competing for the small and medium size entity financial statements. The advantage of the IFRS for SME's is that it will also provide statements that will compare to companies operating in the global business environment. The IFRS for SME's was also in place before FASB started their process to simplify the reporting requirements for small and medium size businesses. On May 23, 2012 the Financial Accounting Foundation (FAF) voted to establish the Private Company Council (PCC). This council was identify and vote on exceptions and modifications to US GAAP for private companies (Tysiac, K., 7/2012). If FASB creates an alternative to the generally accepted accounting principles it may create another framework for these small to medium size entities. 
Table 1. Fundamental difference between International Financial Reporting Standards and United States Generally Accepted Accounting Principles (Based on a 5 point "Likert" scale)

\begin{tabular}{ll}
\hline International Financial Reporting Standards (IFRS) in the United States & 3.1 \\
\hline Principle-based versus rule-based standards & 3.1 \\
\hline Presentation of IFRS based financial statements & 2.6 \\
\hline First time IFRS implementation & 1.8 \\
\hline IFRS for small and medium sized entities & 1.4 \\
\hline
\end{tabular}

The professors scored the coverage of individual differences and convergences of specific standards between IFRS and US GAAP at a higher rate with results of 2.6 to 3.1. The coverage of inventory valuation and revenue recognition scored the highest at 3.1, research and development costs and fair value accounting scored 2.9 and lease accounting scored 2.6 on a scale of 5.0. Many other principles could be discussed but the author choose to limit the scope to these five items because of the importance of each to the process of adoption, endorsement, convergence, condorsement or the methodology the two boards decide when they discuss the similarities and differences of the financial statement presentations.

The major difference in inventory valuation is the use of last-in first-out method of calculating cost of goods sold and ending inventory for an entity. This obstacle is problematic because the Internal Revenue Service requires a consistency in the inventory valuation method. A company switching to first-in first out inventory valuation from last-in first out will have an additional tax liability. This is one of the few areas that the IRS requires consistency and US corporations do not want to expend cash for taxes as a consequence of preparing financial statements using IFRS standards (Adams, M., Troutman, C., 8/2012, p. 60-64). In addition, "inventory measurement might vary when cost is greater than market (US GAAP) or net realizable value (IFRS)" (Price Waterhouse Coopers, 10/2012, p. 82). IFRS also allows for subsequent recovery of inventory written down previously because of the lower of cost or market calculation. This is similar to asset write down procedures. IFRS allows a company to reverse write downs when the market readjusts and the asset recovers value. US GAAP is opposed to allowing corporations to "write up" asset value without a transaction confirming this recovery of value.

Research and development (R\&D) scored 2.6 out of 5.0 on the survey to the professors of accounting at liberal arts universities in Pennsylvania. Research is expensed in IFRS accounting and is also expensed in US GAAP accounting. The difference between the two standards occurs in the treatment of development costs. IFRS will capitalize development costs if certain criteria are met while US GAAP treats development charges as period expenses. "US GAAP does have exceptions and allows special capitalization criteria for in-process R\&D acquired in a business combination, software developed for internal use, software developed for sale to third parties, and motion picture film costs" (KPMG, 10/2012, p. 36)

Fair value measurement coverage also scored 2.6 out of 5.0 on the Likert scale. The fair value measurement criteria for US GAAP and IFRS allows for write downs of value for asset caused by impairment of value because of changing market conditions or new technology. The major difference between the two standards is IFRS allows write ups of asset valuation while US GAAP does not allow this transaction under almost all circumstances. This is problematic because IFRS financial statements may show however asset valuations when restatement occurs and this also creates additional expenditures for depreciation, amortization, and depletion.

Revenue recognition is an example the fundamental difference between IFRS and US GAAP. The convergence project is working on revenue recognition but a fundamental difference exists because the Financial Accounting Standards Board (FASB) and the International Financial Reporting Standards (IASB). FASB is rule based and IFS is principles based. "US GAAP revenue recognition guidance is extensive and tends to be highly detailed and industry-specific. IFRS has two primary revenue standards and four revenue-focused interpretations. The broad principles laid out in IFRS are generally applied without further guidance or exceptions for specific industries" (Price Waterhouse Coopers (PWC), 10/2012, p. 16). The two standard setting agencies are working on the differences and similarities in the rules/principles of when and how much to recognize for various transactions.

The IASB and FASB have agreed to a common lease accounting standard. "The International Accounting Standards Board (IASB) and the Financial Accounting Standards Board (FASB) today agreed on an approach for accounting for lease expenses as part of a project to revise lease accounting in International Financial Reporting Standards (IFRSs) and the U.S. Generally Accepted Accounting Principles (U.S. GAAP)" (IFRS - IASB and FASB agree on 
lease accounting approach, 6/13/2012). This standard will create an asset with a related liability for any lease obligation greater than one year. The current U.S. GAAP rule allows for corporations to not recognize the asset and liability if they meet certain criterion. This is an example of "off balance sheet" financing.

Table 2. Specific accounting topics discussed as important in the convergence process

\begin{tabular}{ll}
\hline Inventory valuation (last in first out) & 3.1 \\
\hline Research and development cost & 2.9 \\
\hline Fair value measurement & 2.9 \\
\hline Revenue recognition & 3.1 \\
\hline Lease accounting & 2.6 \\
\hline
\end{tabular}

The third category of survey questions relate to the methodology that IASB and FASB will use to standardized the accounting regulations for the United States and the rest of the world. The ideas discussed were adoption of IFRS, endorsement, convergence, or condorsement. The last method gained momentum possibly because it is a made up word that does not have a definition. Convergence of standards is likely to be the methodology because the two boards are in the middle of a "convergence" project that has as a goal an understanding of the similarities and differences in the rules/principles of the two boards. The complete approval of the final methodology will need to be completed by the Securities Exchange Committee (SEC). "The SEC has been largely silent on IFRS in the United States since it issued a report on IFRS in July. The report made no recommendation on whether adoption should be allowed or mandated for U.S. public companies" (Tysiak, K., 12/4/2012). The final outcome for aligning these two standard setting agencies is something that may always be a work in progress. University professors may be able to use the concepts to accomplish other goals needed in the accounting curriculum. These standards and differences provide an opportunity to present cultural, political, and economic topics that are the staples of liberal arts based education.

Table 3. Different methods discussed between FASB and the IASB

\begin{tabular}{ll}
\hline Adoption approach for IFRS & 2.0 \\
\hline Endorsement approach for IFRS & 2.2 \\
\hline Convergence approach for IFRS & 2.6 \\
\hline Condorsement approach & 2.3 \\
\hline
\end{tabular}

The fourth category that accounting educators will need to consider is the various cultural, political, and economic topics international accounting considers in standard setting. "The decision on IFRS in the United States rests with the SEC commissioners. But inconsistent implementation across the world due to cultural, business, and economic differences in different countries and regions is a challenge for true comparability within IFRS" (Tysiak, K., 12/4/2012).

The cultural aspects of internationalizing the accounting curriculum scored the highest within this category at a 2.5 with the legal and political differences scoring a 2.4. These two areas could be taught as part of the core competencies within the business curriculum in addition to a focus within the accounting core. The transfer pricing topic is an important consideration in the Cost Accounting course. Transfer pricing scored a 2.2 and international taxation scored a 1.8. International taxation issues would be difficult to address because of the diversity of the tax code but it could be added to the deferred tax material within the intermediate accounting series. The area that provides an interesting pedagogy is the use of financial statement analysis techniques comparing IASB prepared financial statements with US GAAP prepared statements. This will allow coverage of many accounting topics that may need to be restated when analyzing a multinational corporation (MNC).

Table 4. Cultural and legal dimensions

\begin{tabular}{ll}
\hline Cultural differences in application of accounting standards & 2.5 \\
\hline Political and legal differences in application of accounting standards 2.4 & 2.4 \\
\hline International transfer pricing issues 2.1 & 2.1 \\
\hline International taxation issues 1.8 & 1.8 \\
\hline Analysis of foreign financial statements 2.2 & 2.2 \\
\hline Other international issues 2.2 & 2.2 \\
\hline
\end{tabular}




\section{Conclusion}

The importance of International Financial Reporting Standards (IFRS) will increase because of the globalization of business and the process of convergence of US standards promulgated by the Financial Accounting Standards Board (FASB) and the standards of the International Accounting Standards Board (IASB) (Benjamin, M., 2/29/2012). The convergence project has not been endorsed by the Securities Exchange Committee (SEC) causing the listed companies to continue to use US GAAP. "In its 137-page report released in July of 2012, the SEC considered all possible ways to align with International Financial Reporting Standards (IFRS). But the report made it clear, "putting IASB in the driver's seat would be out of the question" (Hoffelder, K., 9/2012, p. 11).

Private colleges and universities must decide where to cover the diversity of topics the global business environment creates because of the different reporting standards but also because of the influence of culture, politics and economics. The Uniform Certified Public Accounting examination will be adding questions concerning these international concepts. The American Accounting Association has a section that discussed international accounting and a section devoted to accounting curriculum. The task at hand is to develop a strategy that will allow private universities to incorporate these concepts either within a stand-alone course or use the strategy of introducing these concepts throughout the curriculum.

Another area where the international standards may be adopted is with the International Financial Reporting Standards for Small and Medium Entities (IFRS for SME's). "In June 2009, the IASB released a special version of IFRS for SME's, often called "IFRS light" (Hoffelder, K., p. 18). This version of international standards is appealing to companies that are engaged in international trade. The survey indicates that this is the least covered topic in the accounting curriculum at universities in Pennsylvania. A possibility exists that the small and medium size businesses will adopt IFRS for SME's to allow their financial results to be compared and evaluated when transacting in foreign trade.

Several of the large CPA firms have written discussion papers concerning the direction the Securities Exchange Commission (SEC) decides to adopt, endorse, converge, or condorse. The condorsement approach required the analyst to make up a word describing the relationship of international standards and the standards required for corporations listed on the United States stock exchanges. "Despite the absence of a recommendation, the SEC staff did seem to tip its hand to the long term endorsement approach" (Securities Exchange Committee, 7/13/2012). This endorsement approach would allow the SEC to pick and choose standards that will be allowed for registered companies listed on the United States stock exchanges. This approach is the follow-up to the convergence project that has made some progress to provide common guidance in areas where a compromise could be reached. The end result is that private university professors will have more material to cover and this material may be changing based on further study of the standard setting procedures.

\section{References}

Adams, M., \&Troutman, C. (2012, August). Avoiding Missteps in the LIFO Conformity Rule: How to Properly Present U.S. GAAP to IFRS Reconciliations. Journal of Accountancy, 60-64.

AICPA, Welcome to the AICPA's IFRS for SMEs - U.S. GAAP Comparison Wiki, (2012, December 10). Retrieved from http://wiki.ifrs.com/

Benjamin, M. (2012, February 29). IFRS Convergence-What it Means and Where it Stands, BPM Accountants and Consultants. Retrieved from http://www.bpmcpa.com/Library/IFRS-Convergence-Update-Feb-2012.asp

Beunaventura Mining 20-F. (2011, November). Retrieved from http://b2icontent.irpass.cc/1454\%2F135217.pdf?AWSAccessKeyId=1Y51NDPSZK99KT3F8VG2\&Expires=13 $55176258 \&$ Signature $=$ OqMHIgR9bWnDCjsg9GF\%2Bxt1xT28\%3D

Deloitte. (2009). US Consulting Debates IFRS Front or Back Burner. Retrieved from http://www.deloitte.com/assets/Dcom-UnitedStates/Local\%20Assets/Documents/us_consulting_debates_IFRSF rontorBackBurner_190209.pdf

FAF creates Private Company Council. (2012, July). Retrieved from http://www.journalofaccountancy.com/Issues/2012/Jul/FAF-creates-Private-Company-Council

Fitzpatrick, M., \& Frank, F. (2009, December). IFRS for SMEs: The Next Standard for U. S. Private Companies. Retreived

from http://www.journalofaccountancy.com/Issues/2009/Dec/20091928.htm?WBCMODE=PresentationUnpublished + ForceRecrawl\%3a+1?action=print 
Grant Thornton. (2012). Now what? Considering IFRS for U.S. issuers Implications of the SEC IFRS work plan for private and public companies. Retrieved http://www.grantthornton.com/staticfiles/GTCom/Grant\%20Thornton\%20Thinking/Resource\%20centers/IFRS \%20Resource\%20Center/IFRS_for_U\%20S\%20_Issuers_Whitepaper_Final.pdf

Henry, E., Lin, S., \& Yang, Y. (2007, November). Weak Signal: Evidence of IFRS and U.S. GAAP Convergence from Nokia's 20-F Reconciliations. Issues in Accounting Education, 22(4), 709-720. http://dx.doi.org/10.2308/iace.2007.22.4.709

Hoffelder, K. (2012, September). SEC Report Backs Away from Convergence. CFO, 11-12.

Hoffelder, K. (2012, September). Mind the GAAP Alternatives. CFO, 17-18.

IFRS - IASB and FASB agree on lease accounting approach. (2012, June 13). Retrieved from http://www.ifrs.org/Alerts/PressRelease/Pages/Leases-13-June-2012.aspx

KPMG. (2012, October). IFRS Compared to US GAAP. Retrieved from http://www.kpmg.com/Global/en/IssuesAndInsights/ArticlesPublications/IFRS-GAAP-comparisons/Documents /IFRS-compared-to-US-GAAP-2012.pdf

Leone, M. (2009, October 8). IFRS Returns to the Front Burner. Retrieved from http://www.cfo.com/article.cfm/14445960?f=most_read

Pennsylvania Colleges Offering a Major in Accounting - College Toolkit. (2012, December 5). Retrieved December 5, 2012, from http://colleges.collegetoolkit.com/colleges/browse/majors/pennsylvania/42/byid/accounting/52.0301.aspx

Price Waterhouse Coopers. (2012, October 18). IFRS and US GAAP Similarities and Differences 2012. Retrieved from

http://www.pwc.com/en_US/us/issues/ifrs-reporting/publications/assets/ifrs-and-us-gaap-similarities-and-differe nces-2012.pdf

Saint Joseph's University website. (2012, December 6). IFRS. Retrieved from http://www.sju.edu/int/academics/hsb/accounting/IFRS.html

Securities Exchange Commission. (2012, July 13). IFRS Work Plan Final Report. Retrieved from http://www.sec.gov/spotlight/globalaccountingstandards/ifrs-work-plan-final-report.pdf

Tysiak, K. (2012, December 4). FASB, IASB union fragile amid SEC indecision on IFRS. Journal of Accountancy. 
Appendix 1. (survey sent to faculty at Pennsylvania Private Colleges and Universities that have a program in accounting)

Do you have an undergraduate course in International Accounting Yes or No

Current coverage of international topics in the accounting curriculum

Current coverage of international topics in the accounting curriculum including the separate International Accounting course (scale of 1 to 5 with five indicating extensive coverage and one indicating limited or no coverage). Your response is based on your coverage of the topics as they relate to international accounting standards and (possibly) how they differ from U.S. GAAP.

Please choose the appropriate response for each item:

International Financial Reporting Standards (IFRS) in the United States

Principle-based versus rule-based standards

Presentation of IFRS based financial statements

First time IFRS implementation

IFRS for small and medium sized entities

Inventory valuation (last in first out)

Research and development cost

Fair value measurement

Revenue recognition

Lease accounting

Adoption approach for IFRS

Endorsement approach for IFRS

Convergence approach for IFRS

Condorsement approach

International transfer pricing issues

International taxation issues

Analysis of foreign financial statements

Cultural differences in application of accounting standards

Political and legal differences in application of accounting standards

$\begin{array}{lllll}1 & 2 & 3 & 4 & 5\end{array}$

O 00000

Other international issues 